Vol. 4, No. 1, 2019

\title{
INTERSTITIAL WATER OF DEEP, STRATIFIED LAKE AS POTENTIAL SOURCE OF INTERNAL PHOSPHORUS LOADING - IMPLICATIONS FOR PREVENTING EUTROPHICATION
}

\author{
Michal Lopata, Renata Tandyrak, Renata Augustyniak, \\ Katarzyna Parszuto, Anna Plachta, Zuzanna Cybulska \\ Department of Water Protection Engineering, Faculty of Environmental Sciences, \\ University of Warmia and Mazury in Olsztyn, \\ 10-720 Olsztyn, Poland, \\ michal.lopata@uwm.edu.pl
}

https://doi.org/10.23939/ep2019.01.032

Received: 12.02 .2019

(C) Łopata M., Tandyrak R., Augustyniak R., Parszuto K., Płachta A., Cybulska Z., 2019

\begin{abstract}
The paper evaluates the potential impact of internal biogenic pollutants (phosphorus) on the trophic state of the deep, stratified Lake Swiete in Obra, Poland (area 23.3 ha, depth $15.3 \mathrm{~m}$ ). The amount of phosphorus in interstitial water was analyzed on the basis of spatial studies of $10 \mathrm{~cm}$ of surface sediments of bottom sediments. It has been shown that the release of loading accumulated in the water can worsen the trophic state of the lake.
\end{abstract}

Key words: bottom sediments, eutrophication, internal loading, interstitial water, phosphorus

\section{Introduction}

Inland water ecosystems are subject to inevitable aging processes. The natural eutrophication of lakes is slow, imperceptibly from the human point of view. However, anthropogenic water reservoirs age considerably faster. The key factor accelerating the problem of the lake's productivity growth is access to biogenic salts. Expansion of urban development, deforestation, agricultural crops as well as atmospheric pollution contribute to increased migration of biogenic salts from the catchment basin to the lake. The most aggressive for aquatic environments impact on eutrophication is sewage discharge. This applies to both discharging pollutants into the lake bowl and its tributaries.

The lake acts as a biological reactor and every load of nutrients is immediately incorporated into the metabolism of hydrobionts [1]. In the period of natural, harmonic eutrophication, nitrogen and phosphorus in the water reservoir occur in small quantities, usually limiting the development of primary producers. Algae biomass is low and they do not threaten the biological balance at the ecosystem level. Light conditions allow for underwater vegetation, stabilizing and limiting the processes of exchange of nutrients in the interphase of water-bottom sediment [2]. The general small amount of organic matter circulating in the trophic chain makes the fish populations remain moderate. This is particularly important from the point of view of the interaction of hydrobionts. Fish populations do not exert excessive pressure on zooplankton, which remains the regulator of planktonic algae under these conditions [3, 4]. No adverse cyanobacterial blooms are observed. This is of particular importance in stratified lakes, i.e. developing thermal levels during the period of water stagnation (epilimnion, metalimnion and hypolimnion). Low trophic status allows to maintain relatively good oxygen conditions in the lowest hypolimnion layer.

The increase in the rate of supply the lake with biogenic substances causes an increase in the production rate of phytoplankton biomass, which impairs the penetration of light into the water column and begins to win competition with submerged macrophytes. Excessive algae biomass dies and sediments forming bottom deposits. In lakes receiving sewage loads, this process is even more violent. With time, the process reaches such a rate that during stagnation of water above the bottom (in the hypolimnion of lakes thermally stratified, and in extreme cases even in metalimnion) oxygen deficits appear, caused by too intensive mineralization of dead auto,- and allochthonous organic matter [5, 6]. Under such conditions, accumulated biogenic matter in bottom sediments is released into the water column as an internal loading of pollution. Especially dangerous is the desorption and diffusion of phosphorus, an element that is considered to be the main factor in water eutrophication $[7,1]$. Identification of these phenomena is the basis for creating correct programs for the protection and reclamation of lakes $[8,9]$. 
The aim of the work was to estimate the level of internal phosphorus loading in a deep, thermally stratified lake in Obra, subject to anthropopressure, based on the study of the content of this element in bottom sediments and interstitial waters.

\section{Experimental part}

\section{Study object}

Lake Swiete in Obra (makroregion WielkopolskoKujawskie Lake District, [10] is rather small, but deep reservoir. It represents dimictic water mixing type - with two circulation (spring and autumn) and two stagnation periods (summer and winter) Max. depth exceeds $15 \mathrm{~m}$ and it is associated with small water table area (max length $1.082 \mathrm{~m}$, max width $257 \mathrm{~m}$ ) and western winds course domination in perpendicular direction to lake axis allows to create of lull thermal stratification. Epilimnion usually is $4 \mathrm{~m}$ deep, the thermocline is located below, with 2-3 $\mathrm{m}$ of thickness, and hypolimnetic cold water zone starts ca. on $10 \mathrm{~m}$ depth [11]. The ice cover is ususally formed during winter. Basic morphometric data of the lake, according to Inland Fisheries Institute in Olsztyn [12], are presented on Fig. 1 and in Table 1.

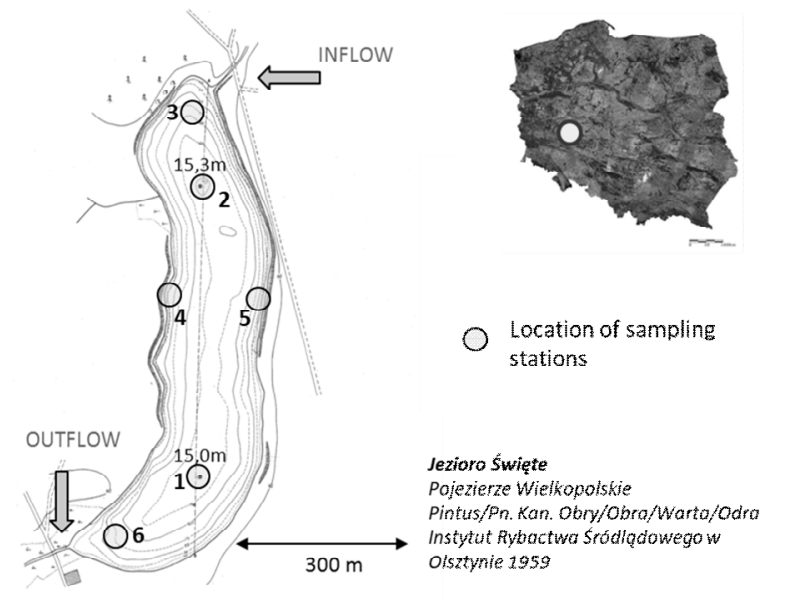

Fig. 1. Location and morphometry of Lake Swiete in Obra with reference to bottom sediments sampling points

Table 1

\section{Main morphometric features of Lake Swiete in Obra [12]}

\begin{tabular}{|c|c|c|}
\hline Parameter & Unit & Value \\
\hline Area & ha & 23.3 \\
\hline Maximum depth & $\mathrm{m}$ & 15.3 \\
\hline Mean depth & $\mathrm{m}$ & 8.9 \\
\hline Elongation & - & 4.2 \\
\hline Water volume & $\mathrm{m}^{3}$ & 2064000 \\
\hline Shoreline: & $\mathrm{m}$ & 2660 \\
\hline $\begin{array}{ll} & \text { development } \\
\text { index } & \end{array}$ & - & 1.56 \\
\hline
\end{tabular}

\section{Methods}

The character of bottom sediments was analyzed on the basis of spatial data from 6 research points $(1$ and 2 - profundal sediments, 3 and 6 - sublitoral sediments, 4 and 5 - littoral sediments). At each point, the samples were collected twice, in July and September 2017. Using a kayak pipe sampler (diameter $50 \mathrm{~mm}$ ). An undisturbed core of the surface layer of $10 \mathrm{~cm}$ was designed for analysis.

\section{Analytical procedures}

The sediment was centrifuged at 3000 r.p.m to obtain interstitial water. After filtration through a filter paper total phosphorus was determined by the blue method according to Standard Methods [13], using Nanocolor UV-VIS spectrophotometer.

The content of main constituents in the bottom sediment was tested in accordance with the method given by Januszkiewicz [14].The sediment analysis included: organic matter as a loss after ignition using weight analysis, silica - using weight analysis after preliminary digestion of a sediment sample in a mixture of the strong mineral acids $\left(\mathrm{H}_{2} \mathrm{SO}_{4}, \mathrm{HClO}_{4}, \mathrm{HNO}_{3}\right.$ 1:2:3) and filtering through No. 390 filter carbonates - using weight analysis in sediment after preliminary pyrolysis and later addition of $\mathrm{CO}_{2}$ saturated water, calcium and magnesium - in filtrate using titration method, iron, manganese, aluminum and phosphorus - in filtrate after mineralization using Merck spectrophotometer, total nitrogen by Kjeldahl method.

\section{Phosphorus external loading calculations}

The calculation of potential phosphorus internal loading in the lake was made basing on morphometric data and current concentration of $P$ in the interstitial water. A linear interpolation method was used to estimate phosphorus content in interstitial waters of individual bottom fragments defined by surfaces contained between particular isobates. As a cartographic material, a bathymetric plan prepared by the Inland Fisheries Institute in Olsztyn was used [12]. Calculations were carried out separately for the northern and southern parts of the lake.

\section{Results and discussion}

For centuries, nature has been recording the history of our planet in specific way. The history of the lakes was recorded in their bottom sediments. The substances found in the water basin are mostly deposited on the bottom, creating a data bank about the past and the 


\section{Michat Łopata, Renata Tandyrak, Renata Augustyniak, Katarzyna Parszuto, Anna Ptachta at all}

current state of the lakes. $[15,16]$. Bottom sediments are a recorder of geomorphological phenomena and processes occurring in the aquatic environment. The information about the source of materials sinking to the bottom recorded in bottom sediments, their impact on water quality, or biological systems dominating in the lake are an important factor in the study of water quality [17]. Sediment chemistry plays the role of an indicator when assessing the degradation of water reservoirs, environmental pollution, and also allows to solve many problems of the limnological nature. From the point of view of protecting the lake against eutrophication, the most important aspect is the process of exchange of biogenic substances between water and bottom sediments. It is widely accepted that the potential for the release of phosphorus from bottom sediments depends on their chemical composition $[16,7,18]$. In particular, components showing affinity for phosphorus such as iron, aluminum, manganese and calcium are able to control the circulation of this element between water and sediments.

Our research has shown that the composition of sediment is strongly spatially diverse. Littoral sediments (stands 4 and 5) definitely distinguished themselves by the dominance of the mineral component, primarily silica.

Table 2

Average contents of macrocomponents in bottom sediments of the Lake Swiete in Obra ( $\%$ of dry matter, $n=4$ )

\begin{tabular}{|l|c|c|c|}
\hline Component & Littoral & Sublittoral & Profundal \\
\hline silica $\left(\mathrm{SiO}_{2}\right)$ & 94.35 & 46.85 & 38.36 \\
\hline organic matter & 1.89 & 17.97 & 17.76 \\
\hline $\begin{array}{l}\text { Calcium } \\
\text { carobnate } \\
\left(\begin{array}{l}\text { sum CaO i } \\
\left.\mathrm{CO}_{2}\right)\end{array}\right.\end{array}$ & 2.46 & 31.13 & 39.76 \\
\hline $\begin{array}{l}\text { magnesium } \\
(\mathrm{MgO})\end{array}$ & traces & 0.79 & 0.85 \\
\hline $\begin{array}{l}\text { aluminum } \\
\left(\mathrm{Al}{ }_{2} \mathrm{O}_{3}\right)\end{array}$ & 0.11 & 1.23 & 0.67 \\
\hline iron Fe $\mathrm{O}_{3}$ & 0.10 & 0.70 & 0.62 \\
\hline $\begin{array}{l}\text { manganese } \\
\mathrm{MnO}^{\text {nnO }}\end{array}$ & 0.02 & 0.12 & 0.03 \\
\hline nitrogen $\mathrm{N}$ & 0.17 & 1.04 & 1.13 \\
\hline $\begin{array}{l}\text { phosphorus } \\
\left(\mathrm{P}_{2} \mathrm{O}_{5}\right)\end{array}$ & 0.05 & 0.33 & 0.38 \\
\hline
\end{tabular}

The content of components making up the active sorptive complex of bottom sediments in the lake studied was small. The total percentage share of iron, aluminum and manganese is only about $3.5 \%$. Under such conditions, phosphorus is weakly bound in bottom sediment, and taking into account the relatively higher content of calcium carbonate and organic matter, it should be assumed that the main form of its deposition in the bottom is co-precipitation with these components.

Indeed, the amount of total phosphorus in the bottom sediments of the Lake Swiete can be described as small. Calculated on the pure component, they ranged from $0.189-0.231 \mathrm{mg} \cdot \mathrm{P} / \mathrm{g} \mathrm{d} . \mathrm{w}$. in the shallowest positions ( 5 and 4 , respectively) to $1.678 \mathrm{mg} \cdot \mathrm{P} / \mathrm{g} \mathrm{d} . \mathrm{w}$. on stand 1 . This proves the limited sorption capacity of the tested sediments in relation to phosphorus. In eutrophic lakes, the content of total phosphorus in bottom sediments may be much higher - on the order of a few or even a dozen or so $\mathrm{mg} \cdot \mathrm{P} / \mathrm{g}$ d.w. $(1,19,20]$.

The geochemical background of bottom sediments is not the only factor that affects the release of phosphorus from the lake bottom solids. A very important element is also oxidoreductive potential, which is the result of oxygen conditions. Iron compounds that play an important role of phosphorus binding in the aqueous environment retain the ability to attach phosphate ions under the condition that the threshold oxygen concentrations in interphase waters remain constant (about $1 \mathrm{mgO}_{2} / \mathrm{dm}^{3}$ ). With deep deoxidation of the bottom waters, the slightly soluble Fe (III) hydroxides become Fe (II) and release phosphorus into water. Thus, the internal loading phenomenon usually intensifies with the progress of eutrophication $[21,18]$. In lakes with advanced trophies, the "vicious circle of eutrophication" sometimes occurs. Primary production in the lake is so large that the sedimenting organic matter causes complete deoxidation of the bottom waters. This in turn favors the internal release of phosphorus from the bottom to the bottom layers (in the case of lakes stratified to hypolimnion), while in the autumn this load is distributed throughout the mass of waters as a result of their circulation. It is an additional biogenic load, which in the following growing season stimulates planktonic algae to growth even more. This causes a higher rate of biomass production, which after sedimentation again, but more intensively results in deoxidation of water. The cycle repeats itself in the following years and acting on the basis of feedback does not allow to improve trophic conditions even after cutting off external sources of pollution [22]

In the studied lake there are conditions for the appearance of the described phenomena. The lake is relatively deep, with a small area. The theoretical range of wind mixing is just $3.6 \mathrm{~m}$ and coincides with the real range of epilimnion [11]. Water stratification is therefore very severe, and the existence of layers is very long (May - October). This is conducive to increasing 
oxygen deficits and considering the current trophic status (eutrophy) and the character of bottom sediments (a high proportion of organic matter, high immediate oxygen demand) may unfortunately result in the release of phosphorus from bottom sediments into the water.

The results of sediment and bottom water surveys confirm this thesis. All analyzed measuring points were characterized by a clear predominance of phosphorus concentrations in interstitial waters over concentrations of this element found above the sediment. A synthetic summary of the results obtained is presented in Table 3 .

Table 3

Average phosphorus content in the sedimentary waters of the Lake Swiete in Obra $\left(\mathrm{mgP} / \mathrm{dm}^{3}, \mathrm{n}=4\right)$

\begin{tabular}{|l|l|l|l|}
\hline \multicolumn{1}{|c|}{ layer } & littoral & sublittoral & profundal \\
\hline $\begin{array}{l}\text { Near-bottom water } \\
(10 \mathrm{~cm} \text { above } \\
\text { sediments table })\end{array}$ & 0.148 & 0.185 & 0.462 \\
\hline $\begin{array}{l}\text { Interstitial water } \\
(10 \mathrm{~cm} \text { thickness of } \\
\text { surface sediments })\end{array}$ & 1.620 & 2.212 & 8.320 \\
\hline
\end{tabular}

The results also clearly indicate the differentiation of the rate of phosphorus secretion from the bottom of various types - the least favorable conditions prevail in the deep profundal, which is under the influence of the longest lasting oxygen deficits in the lake year cycle. The conditions for the release of phosphates into the water from the bottom sediment in Lake Swiete are unfortunately advantageous, because a clear gradient of concentrations of this element in various parts of the column of water promotes ion diffusion (Fig. 2).

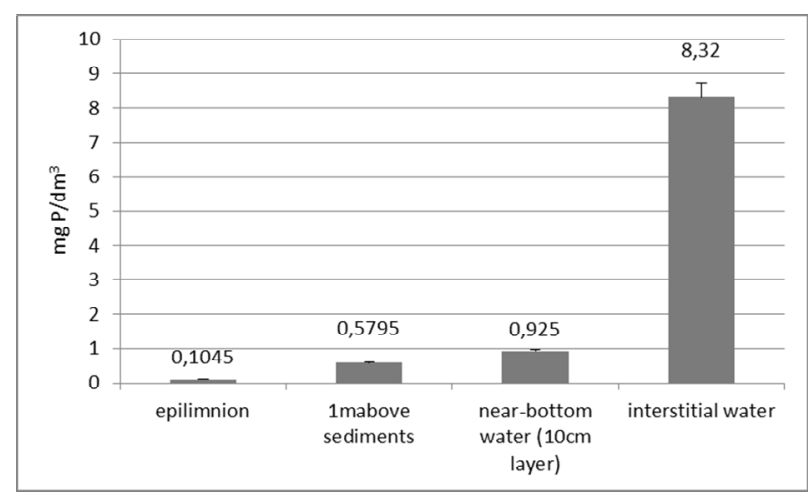

Fig. 2. Differences in phosphorus concentrations in individual parts of the Lake Swiete $(n=4)$

The abundance of biogenic substances in the sedimentary water layers is the premise of the processes of self-feeding of the lake with indigenous matter. However, in order to determine the potential impact of this phenomenon on the formation of water trophic status and thus the threat to the recreational and natural values of the basin, the data obtained should be referred to the lake scale. Not always the presence of increased concentration of nutrients in bottom sediments must mean a threat to water. It will depend on the relation of the pollution stored in the bottom to the water volume (the ability to dilute pollutants in lake water). As a rule, the upper layer of approximately $10 \mathrm{~cm}$ layer participates in the processes of substance exchange in the interphase of the water-bottom sediment $[1,18]$. The deeper deposits may also affect the water surface, especially if they undergo bioturbation processes due to penetration by the organisms feeding in the bottom (benthivorous fish, invertebrates).

To illustrate the potential impact of the phosphorus pool released into the interstitial waters of the studied lake, the results were analyzed for the actual amount of biogenic matter discharged into the sedimentary waters. According to the literature, it was assumed that the first $10 \mathrm{~cm}$ of bottom sediment participates in the exchange of ions in the interphase. After taking into account the surface of individual lake fragments and physical properties of the sediment, the phosphorus loading contained in the analyzed layer was calculated (table 4).

Table 4

The content of phosphorus in interstitial water of individual fragments of the bottom of Lake Swiete

\begin{tabular}{|c|c|c|c|}
\hline $\begin{array}{l}\text { Surface } \\
\text { limited by } \\
\text { isobaths }\end{array}$ & Area [ha] & $\begin{array}{l}\text { The volume } \\
\text { of water in } \\
\text { the } 10 \mathrm{~cm} \\
\text { sediment } \\
\text { layer }\left[\mathrm{m}^{3}\right]\end{array}$ & $\begin{array}{c}\text { Unit load } \\
{[\mathrm{kg}]}\end{array}$ \\
\hline \multicolumn{4}{|c|}{ Northern part } \\
\hline$>12.5$ & 3.05 & 2836.5 & 21.32 \\
\hline $12.5-10.0$ & 2.95 & 2743.5 & 15.84 \\
\hline $10.0-7.5$ & 1.85 & 1720.5 & 6.93 \\
\hline $7.5-5.0$ & 1.35 & 1255.5 & 3.41 \\
\hline $5.0-2.5$ & 1.15 & 1069.5 & 2.41 \\
\hline $2.5-1.0$ & 0.7 & 651.0 & 1.25 \\
\hline $1.0-0.0$ & 0.55 & 511.5 & 0.26 \\
\hline \multicolumn{3}{|c|}{ sum } & 51.41 \\
\hline \multicolumn{4}{|c|}{ Southern part } \\
\hline$>12.5$ & 2.85 & 2650.5 & 19.78 \\
\hline $12.5-10.0$ & 2.65 & 2464.5 & 14.50 \\
\hline $10.0-7.5$ & 2.05 & 1906.5 & 8.21 \\
\hline $7.5-5.0$ & 1.55 & 1441.5 & 3.93 \\
\hline $5.0-2.5$ & 1.25 & 1162.5 & 1.95 \\
\hline $2.5-1.0$ & 0.80 & 744.0 & 1.30 \\
\hline $1.0-0.0$ & 0.55 & 511.5 & 0.26 \\
\hline \multicolumn{3}{|c|}{ sum } & 49.93 \\
\hline
\end{tabular}


The total load collected in the analyzed layer during the research period was determined to be $101.3 \mathrm{~kg}$. Its release into the lake waters would result in an increase in the concentration in the hypolimmion (volume $406600 \mathrm{~m}^{3}$, [11]) by $0.25 \mathrm{mg} \cdot \mathrm{P} / \mathrm{dm}^{3}$. This is an additional pool that almost doubles the fertility of this layer of water. In turn, the distribution of this load throughout the lake (during the autumn water circulation) would theoretically increase the concentration of phosphorus by $0.05 \mathrm{mg} \cdot \mathrm{P} / \mathrm{dm}^{3}$. Considering the content of this element in surface waters (about $0.1 \mathrm{mgP} / \mathrm{dm}^{3}$ ) this load would constitute an additional $50 \%$ of the present content. In a situation where the value of $0.1 \mathrm{mgP} / \mathrm{dm}^{3}$ is considered to be borderline between eutrophy and hypertrophy [23], such a scenario should be considered highly unfavorable. It should be remembered that bottom sediments are not the only source of pollution. The lake, like any aquatic ecosystem, also has contact with matter flowing from the catchment.

According to the Vollenweider criteria [24], the critical load for Lake Swiete is $59.2 \mathrm{~kg}$ [11]. Therefore, the potential risk of phosphorus release only from internal sources is almost twice exceeding the level of biogenic matter inflow, which would allow a smooth course of the eutrophication process. Therefore, in order to effectively counteract the effects of excessive trophic waters, it is not enough to limit the nutrient supply from the basin, but also to eliminate or at least minimize the phenomenon of internal loading

According to the premises resulting from the research, the right action for the revitalization of Lake Swiete in Obra will be the supply of oxygen to the nearbottom waters during periods of oxygen deficits. Due to the strong thermal stratification, it is not justified to use aeration techniques with destratification, but selective oxygenation of hypolimnion waters. The methods that are used for this purpose are widely described in the literature $[25,26,9]$. An interesting proposition may be to use the existing stream as an oxygenated water supplier and redirect it via a pipeline to the bottom layers. This solution was proposed [27] and implemented with a good effect on another eutrophicated lake in Poland.

Taking into account the chemical composition of bottom sediments, especially the poverty of phosphorusbinding components, the next reclamation action applied parallel to oxygenation should be the application of phosphorus inactivating agents - e.g. widely used in the reclamation of lakes of iron and aluminum based coagulants. These compounds, used as standard in water and wastewater treatment, are also suitable for precipitation of excess phosphorus from natural waters. The condition for the effectiveness of the process, however, is a well-planned design of the application, taking into account the required doses and the potential environmental risk associated with the use of acidic salts of these elements, especially aluminum, which, as an amphoteric element, can be toxic to hydrobionts in water. Nevertheless, the experience of scientists in Poland [28-32] and in the world [25, 26] indicate that the above treatments can effectively and permanently revitalize the lake ecosystem.

The results of these studies show once again that lakes are very fragile ecosystems, susceptible to degradation, hence the best practice in managing these valuable landscape elements should be prevention against the inflow of pollutants [33]. Preventing the development of eutrophication is a much more environmentally favorable scenario than spectacular, but expensive and not always successfully completed lake reclamation programs.

\section{Conclusions}

The morphometric conditions of Lake Swiete in Obra allow the occurrence of persistent thermal stratification in the summer. Basically, stratified lakes eutrophicate slower than polymictic lakes. However, in the case of Lake Swiete, both metalimnion and hypolimnion are characterized by the occurrence of oxygen deficits. Bottom sediments of the lake ceased to accumulate phosphorus efficiently. Under anaerobic conditions in the lake's profundal, which prevail for most of the year, there is an excessive reduction of the oxidation-reduction potential in the interphase of the water-sediment. Phosphorus is released into the interstitial waters and further into the lake water, while during short periods of water circulation (spring and autumn), this matter released from the bottom goes to the surface layers stimulating the eutrophication of the lake. This causes the lake to load additional matter (hydrogen sulfide, mineral phosphorus released from bottom sediments) that is unfavorable for the ecosystem from the point of view of ecological balance. Unfavorable hydrochemical conditions in the lake make it necessary to intervene. The work proposed directions for revitalization activities. They should be directed at limiting the further inflow of pollutants, followed by the improvement of aerobic conditions and limitation of the possibility of phosphorus release from the sediment to interstitial waters and to the water column. 


\section{References}

[1] Kajak Z., 2001. Hydrobiology - limnology. Inland water ecosystems (in Polish). PWN, Warsaw.

[2] Scheffer M.,1990. Multiplicity of stable states in freshwater systems. Hydrobiologia 200/201: 475-486.

[3] Gołdyn R., 2000. Shines and shadows of biomanipulation on the example of the Maltanskie Reservoir in Poznań (in Polish). Proceedings of the IX Scientific Conference "Ochrona i rekultywacja jezior" Polish Association of Sanitary Engineers and Technicians, Przysiek, 145-153.

[4] Shapiro J., Wright DI.,1984. Lake restoration by biomanipulation. Round Lake, Minnesota - the first two years. Freshwat.Biol. 14: 371-383.

[5] Boström B., Jansson M., Forsberg C., 1982. Phosphorus release from lake sediments. Arch. Hydrobiol. Beih. 18, $5-59$.

[6] Forsberg C., 1989. Importance of sediments in understanding nutrient cyclings in lakes. Hydrobiologia, 176/177, 263-277.

[7] Golterman H. L., 2001. Phosphate release from anoxic sediments or "What did Mortimer really write?". Hydrobiologia, 450: 99-106.

[8] Gawrońska H., Lossow K., 2008. Lake restoration limitations and practical indications (in Polish). In: Jasser I, Robak S, Zdanowski B (eds.): Ochrona i rekultywacja wód Wielkich Jezior Mazurskich narzędziem rozwoju naukowego, gospodarczego, społecznego i kulturowego regionu. Inland Fishery Institute in Olsztyn, 39-51.

[9] Łopata M., 2013. Lake restoration - methods, conditions, stages of activities (in Polish). In: Domagała J., Czerniawski R, Pilecka-Rapacz M. (eds.) Antropopresja na ekosystemy wodne a ochrona przyrody i aktywizacja rybactwa. Uniwersytet Szczeciński. Barlinek, 61-83.

[10] Kondracki J., 1998. Regional geography of Poland (in Polish). PAN, Warsaw.

[11] Grochowska J., Czerniawski R., Łopata M., Tandyrak R., Parszuto K., Augustyniak R., Karpienia M., Płachta A., 2018. "Eutrophication of Lake Swiete in Obra: ecological status, threats, possibility of protection and restoration. University of Warmia and Mazury in Olsztyn, pp. 96.

[12] Inland Fisheries Institute in Olsztyn, 1959. Bathymetry and morphometric card of Lake Swiete, PO-5/5-89/59.

[13] Standard Methods for the Examination of Water and Wastewater, 2005, 21st edn, American Public Health Association, Washington DC, USA, pp. 1368.

[14] Januszkiewicz T., 1978. Studies on the methodology of chemical analysis of the composition of modern bottom sediments of lakes (in Polish). Zesz. Nauk. ART Olszt., Ochr. Wód i Ryb. Śródl. 8: 3-30.

[15] Augustyniak R. (2018). The influence of physical, chemical and microbiological factors on the phosphorus internal loading to the water of selected urban lakes (in Polish). Monograph of Environmental Engineering
Comitee of PAS, Perfekta.info Publishing House, pp 230.

[16] Bartoszek L., 2007. Release of phosphorus from bottom sediments (in Polish). Zeszyty Naukowe Politechniki Rzeszowskiej. Budownictwo i Inżynieria Środowiska 240, 42: 5-20.

[17] Mushtaq B., Rajni R., Yousuf A. R., Wanganeo A., Ahafi N., Manhas A., 2015. Chemical Characteristics of Bottom Sediments of Dal Lake Srinagar, Kasmir. Journal of Environmental Protection and Sustainable Development 1 (1): 1-7.

[18] Søndegaard M., J. P. Jensen, E. Jeppesen, 2003. Role of sediment and internal loading of phosphorus in shallow lakes. Hydrobiologia 506-509: 135-145.

[19] Kentzer A., 2001. Phosphorus and its biologically available fractions in sediments of lakes of various trophies (in Polish). UMK, Torun.

[20] Łopata M., H. Gawrońska, 2008. Phosphorus immobilization in Lake Głęboczek following treatment with polyaluminium chloride. Oceanol. Hydrobiol. Stud, 37(2): 99-105.

[21] Augustyniak R., Neugebauer M., Kowalska J., Szymański D., Wiśniewski G., Filipkowska Z., Grochowska J., Łopata M., Parszuto K., Tandyrak R., 2017. Bottom deposits of stratified, seepage, urban lake (on the example of Tyrsko lake, Poland) as a factor potentially shaping lake water quality, Journal of Ecological Engineering 18(5): 55-62.

[22] Jeppesen E., Søndergaard M., Jensen J. P., Havens K. E., Anneville O., Carvalho L., Coveney M. F., Deneke R., Dokulil M. T., Foy B., 2005. Lake responses to reduced nutrient loading - an analysis of contemporary long-term data from 35 case studies. Freshw. Biol., 50: 1747-1771

[23] OECD, 1982. Eutrophication of Waters - Monitoring, Assessment and Control. The Organisation for Economic Cooperation and Development (OECD), Paris, pp.154.

[24] R. A. Vollenveider, 1976. Advances in defining critical loading levels for phosphorus in lake eutrophication, Mem. Ist. Ital. Idrobiol., 33: 53-83.

[25] Cooke G. D., Welch E. B., Peterson S. A., Nichols S. A., 2005. Restoration and Management of Lakes and Reservoirs. Taylor \& Francis/CRC Press, pp. 616.

[26] Klapper H., 1991. Control of eutrophication in inland waters. Ellis Hornwood, New York.

[27] Łopata M., Wiśniewski G., 2013. The use of surface water flow to improve oxygen conditions in a hypertrophic lake. Global Journal on Advances Pure and Applied Sciences, vol 1: 710-715.

[28] Grochowska J., Brzozowska R., Łopata M., 2013. Durability of changes in phosphorus compounds in water of an urban lake after application of two reclamation methods. Water Science and Technology, 68(1): 234-239.

[29] Grochowska J., Augustyniak R. Łopata M. 2017a. How durable is the improvement of environmental conditions in a lake after the termination of restoration treatments? Ecological Engineering, 104: 23-29. 
[30] Grochowska J. K., Brzozowska R., Parszuto K., Tandyrak R., 2017b. Modifications in the trophic state of urban lake, restored by different methods, Journal of Elementology 22(1): 43-53.

[31] Łopata M, Gawrońska H, Wiśniewski G, Jaworska B (2013) Restoration of two shallow, urban lakes using the phosphorus inactivation method - preliminary results. Water Science and Technology 68(10): 2127-2135.
[32] Rosińska J., Kozak A., Dondajewska R., Kowalczewska-Madura K., Gołdyn R., 2018. Water quality response to sustainable restoration measures case study of urban Swarzedzkie Lake. Ecological Indicators, 84: 437-449.

[33] Lossow K.,1998. Protection and reclamation of lakes. Theory and practice (in Polish). Idee Ekologiczne 13: $55-70$. 